\title{
American Journal of Pediatrics
}

\section{Seasonality of Vitamin D Insufficiency in Children of Moscow}

\author{
Zakharova Irina ${ }^{1,}$, , Borovik Tatyana ${ }^{6}$, Pludowski Pawel ${ }^{7}$, Tvorogova Tatyana ${ }^{1}$, \\ Solovyeva Ekaterina ${ }^{1,2}$, Sugyan Narine ${ }^{1,2}$, Antonenko Natalia ${ }^{3}$, Balashova Nadejda ${ }^{3}$, \\ Kuular Nadejda ${ }^{3}$, Marchenko Vera ${ }^{3}$, Perova Svetlana ${ }^{3}$, Prostakova Valentina ${ }^{3}$, Simakova Natalia ${ }^{3}$, \\ Simonenko Irina ${ }^{3}$, Vasilyeva Svetlana ${ }^{1}$, Mozzhukhina Maria ${ }^{1}$, Koroleva Ekaterina ${ }^{4}$, \\ Rakhteenko Alina $^{1}$, Dmitrieva Yulia ${ }^{1}$, Klimov Leonid ${ }^{5}$, Kuryaninova Victoria ${ }^{5}$ \\ ${ }^{1}$ Department of Pediatric, FSBEI HPT “Russian Medical Academy of Postgraduate Continuing Education” of the Ministry of Health, \\ Moscow, Russia Federation \\ ${ }^{2}$ Department of Pediatric, SBHI “Pediatric Municipal Polyclinic № 133” of the Moscow Health Department, Moscow, Russia Federation \\ ${ }^{3}$ Department of Pediatric, FSBI "Pediatric Medical Center" of the Presidential Administration of the Russian Federation, Moscow, Russia \\ Federation \\ ${ }^{4}$ Department of Pediatric, Clinic of Group of Companies "Mother and a Child", Moscow, Russia Federation \\ ${ }^{5}$ Department of Pediatric, FSBEI HE "Stavropol State Medical University” of the Ministry of Health, Stavropol, Russia Federation \\ ${ }^{6}$ Department of Nutrition Children, FSAI «National Scientific and Practical Center of Children's Health» of the Ministry of Health, Moscow, \\ Russia Federation \\ ${ }^{7}$ Department of Biochemistry and of Experimental Medicine, The Children's Memorial Health Institute, Warsaw, Poland
}

\section{Email address: \\ kafedra25@yandex.ru (Z. Irina) \\ ${ }^{*}$ Corresponding author}

\section{To cite this article:}

Zakharova Irina, Borovik Tatyana, Pludowski Pawel, Tvorogova Tatyana, Solovyeva Ekaterina, Sugyan Narine, Antonenko Natalia, Balashova Nadejda, Kuular Nadejda, Marchenko Vera, Perova Svetlana, Prostakova Valentina, Simakova Natalia, Simonenko Irina, Vasilyeva Svetlana, Mozzhukhina Maria, Koroleva Ekaterina, Rakhteenko Alina, Dmitrieva Yulia, Klimov Leonid, Kuryaninova Victoria. Seasonality of Vitamin D Insufficiency in Children of Moscow. American Journal of Pediatrics. Vol. 3, No. 6, 2017, pp. 83-88. doi: 10.11648/j.ajp.20170306.14

Received: July 11, 2017; Accepted: October 23, 2017; Published: November 30, 2017

\begin{abstract}
The article presents the analysis of vitamin D levels in children of various age groups residing in Moscow and assesses the seasonality of vitamin D variations in this population group. In this work, the results of $25(\mathrm{OH}) \mathrm{D}$ level measurement in 1041 children in the age from 1 month to 18 years collected in the period since 2012 to 2015 have been analyzed. In accordance with the analysis, in spite of the age, the high percentage of vitamin D insufficiency was detected among children in Moscow. The generally accepted optimum level of vitamin D metabolite - calcidiol in blood ( $>30 \mathrm{ng} / \mathrm{ml}$ ) was observed only in the small part of the study participants (26\%), while the larger part (74\%) had the insufficient level of vitamin D of various intensity: $28 \%$ - insufficiency $(20-29 \mathrm{ng} / \mathrm{ml}), 33 \%$ - deficiency $(<20 \mathrm{ng} / \mathrm{ml}), 13 \%$ - severe deficiency $(<10$ $\mathrm{ng} / \mathrm{ml})$. With the age, the insufficiency level was more pronounced. The seasonality analysis showed the significant difference of vitamin D level between summer and winter seasons $(\mathrm{p}=0.01)$. The greatest decrease of vitamin $\mathrm{D}$ levels was observed in winter (median level of 25(OH)D $17.0(11.0 ; 25.0) \mathrm{ng} / \mathrm{ml})$. In summer months, the relative calcidiol gain was fixed (median $22.9(18.0 ; 33.0) \mathrm{ng} / \mathrm{ml})$ which, however, did not achieve the normal level. Children and, in particular, adolescents residing in Moscow need year-round hypovitaminosis D prophylaxis with cholecalciferol products.
\end{abstract}

Keywords: Vitamin D, Cholecalciferol, Hypovitaminosis D, Vitamin D Deficiency, Seasonal Variations of Vitamin D 


\section{Introduction}

Currently, there is a big number of fundamental and clinical studies related to various biological effects of vitamin $\mathrm{D}$ and its favorable health effect. If the disorder of phosphorus - calcium metabolism and other bone metabolism disorders were previously considered as the main point of vitamin D therapy, nowadays, the considerable complex vitamin D effect on numerous body systems has become gradually evident. The main differential characteristic of vitamin D in comparison with other vitamins is its steroid chemical structure and presence of the specific receptor to its active metabolite $1.25(\mathrm{OH})_{2} \mathrm{D}$ in various body tissues. It allows to consider vitamin $\mathrm{D}$ as a steroid hormone. Its functions are mediated by the nuclear receptor (VDR vitamin $\mathrm{D}$ receptor) which induces transcriptional alterations on the genetic level affecting growth and inflammation factor levels, activity of various proteins and hormone levels in blood. It is known that vitamin $\mathrm{D}$ affects both directly and indirectly the expression of about $1250-5000$ genes $[1,2]$.

The investigators have revealed the relationship of vitamin D deficiency and:

cardiovascular diseases (arterial hypertension, myocardial infarction, cardiogenic stroke);

manifestation of autoimmune diseases (1 type diabetes mellitus, multiple sclerosis, Crohn's disease, rheumatoid arthritis, systemic lupus erythematosus);

higher frequency of acute respiratory infection;

allergic pathology (bronchial asthma and atopic dermatitis);

cancer diseases (pancreatic cancer, colorectal cancer, breast cancer) $[2,3,4]$.

In the recent years, a favorable effect of the vitamin on nervous system development, neuroprotective and neurotrophic effect on CNS has been proven in children and adolescents $[1,5]$. The relationship between the sufficient vitamin D intake and increase of mean population life span has been demonstrated.

The wide range of vitamin D effects on human health, in particular health of a child that acutely needs vitamin D on each stage of his/her development, have been of great interest for scientists and physicians already for several decades. In spite of this fact, the prevalence of D-deficient status remains currently rather high and requires decisive steps to overcome it.

It is known that only $5 \%$ of vitamin $\mathrm{D}$ is received with food, and the rest of $95 \%$ shall be synthesized in skin under exposure of UV-irradiation [6]. However, due to the geographic location of the country - above $40^{\circ}$ the north latitude, the residents of the Russian Federation have the increased risk of a lower vitamin D status due to insufficient insolation and reduced epidermal synthesis [7].

There is some rather contradictory data on the presence of seasonal variations of serum calcidiol concentration. For example, the study carried out in Denmark assessed the vitamin $\mathrm{D}$ levels in girls aged 11-13 years during winter and summer. The better calcidiol level was detected in summer months. It was also proven that in case of $25(\mathrm{OH}) \mathrm{D}$ level $40 \mathrm{ng} / \mathrm{ml}$ in summer, 25(OH)D level of $20 \mathrm{ng} / \mathrm{ml}$ may be achieved next winter [8]. In Great Britain, the peak blood level of vitamin D was observed in autumn months [9]. In addition, several works on adults and children have shown that $25(\mathrm{OH}) \mathrm{D}$ level decreases on $24-42 \%$ to winter period in comparison with "summer" level [10, 11, 12, 13].

The necessity to develop recommendations for pediatricians on hypovitaminosis D prophylaxis in children and adolescents was the rationale for the series of studies on the determination of vitamin D status in child population.

Despite the divergences in determination of the criterion of normal blood level of vitamin D metabolite (calcidiol) according to various authors, the most prevalent point of view of experts are the following values: in severe vitamin $\mathrm{D}$ deficiency, serum 25(OH)D level was less than $10 \mathrm{ng} / \mathrm{ml}$, in deficiency - less than $20 \mathrm{ng} / \mathrm{ml}$, in insufficiency - in the range $21-29 \mathrm{ng} / \mathrm{ml}$. The target serum calcidiol concentration that characterizes the normal levels corresponds to the level above $30 \mathrm{ng} / \mathrm{ml}[3,7,14]$. The concentration allows to achieve positive effects of vitamin $\mathrm{D}$ on human body including bone metabolism: the study with flank bone biopsy showed the significant improvement of bone density in patients with $25(\mathrm{OH}) \mathrm{D}$ level above $30 \mathrm{ng} / \mathrm{ml}$, while among patients with the level of 21-29 ng/ml, the amount of biopsies with osteomalacia signs was $21 \%$ [15]. Based on the literature data, blood level of vitamin D above 150-200 $\mathrm{ng} / \mathrm{ml}$ is considered to be excessive which may manifest as development of hypercalcaemia, hypercalciuria or hyperphosphatemia [16].

Study aim: to examine vitamin D provision in children and detect its relationship with the age group and year season among the Moscow residents.

\section{Study Materials and Methods}

The retrospective analysis was made using laboratory values of 1041 children aged from 1 month to 18 years which were supervised in treatment prevention institutions of Moscow in the period 2012 to 2015. 259 patients aged from 2 months to 18 years at the polyclinic at the Presidential Administration, 360 patients aged 10-18 years from municipal polyclinic № 133 and 100 adolescent girls aged 11-17 years from the cadet corps were examined. 322 younger children ( 1 month -3 years) were also enrolled to the study that were examined at the base of Z. A. Bashlyaeva Pediatric Municipal Clinical Hospital and polyclinic of Group of companies "Mother and child".

To assess vitamin $\mathrm{D}$ status in blood, the content of the main metabolite of vitamin $\mathrm{D}$ was determined $-25(\mathrm{OH}) \mathrm{D}_{3}$ (25-hydroxyvitamin D or calcidiol). While analyzing the results, we relied on standard serum $25(\mathrm{OH}) \mathrm{D}$ values developed during research studies: over $30 \mathrm{ng} / \mathrm{ml}$ - sufficient levels; 21-29 $\mathrm{ng} / \mathrm{ml} \mathrm{-} \mathrm{insufficient} \mathrm{levels;} 10-20 \mathrm{ng} / \mathrm{ml}$ deficiency; less than $10 \mathrm{ng} / \mathrm{ml}$ - severe deficiency [3, 17, 18].

For statistical data processing, software package IBM SPSS 
Statistics was used (version 20.0.0). The results were processed using generally accepted parametric and non-parametric comparison methods. Quantitative data was presented as median and interquantile range (Me [25Q; 75Q]).

\section{Study Results}

In accordance with the data obtained during the study, the prevalence of vitamin D deficiency in various age groups of the Moscow pediatric population remains very high. Sufficient $25(\mathrm{OH}) \mathrm{D}$ level $(>30 \mathrm{ng} / \mathrm{ml})$ was observed in the small part - in $26 \%$ patients, while $74 \%$ of the population demonstrated hypovitaminosis D of various intensity; $28 \%$ had insufficiency $(20-29 \mathrm{ng} / \mathrm{ml}), 33 \%$ - deficiency $(<20$ $\mathrm{ng} / \mathrm{ml})$, and $13 \%$ - severe vitamin D deficiency $(<10 \mathrm{ng} / \mathrm{ml})$.

It should be especially noted that the sufficient calcidiol level in blood was observed only in the group of patients of the first year of life, while already from the age of two years, the larger part of the study participants had vitamin D insufficiency and its prevalence only increases with the age (table 1).

Table 1. Median 25(OH)D level in various age groups.

\begin{tabular}{ll}
\hline Age group & Median level of vitamin D $(\mathbf{n g} / \mathbf{m l})$ \\
\hline up to 1 year & $34.2(25 ; 51)$ \\
1 year & $30.5(21 ; 45)$ \\
2 years & $24.0(20 ; 38)$ \\
3 years & $27.0(23 ; 36)$ \\
4-6 years & $25.0(22 ; 31)$ \\
7-9 years & $27.0(23 ; 36)$ \\
10-12 years & $15.0(11 ; 22)$ \\
13-16 years & $17.0(11 ; 22)$ \\
17-18 years & $17.0(13 ; 21)$ \\
\hline
\end{tabular}

While analyzing variations of blood level of vitamin D depending on the month of measurements, we obtained just small differences in values (figure 1).

\section{Level of $25(\mathrm{OH}) \mathrm{D3} \mathrm{ng} / \mathrm{ml}$ in various months}

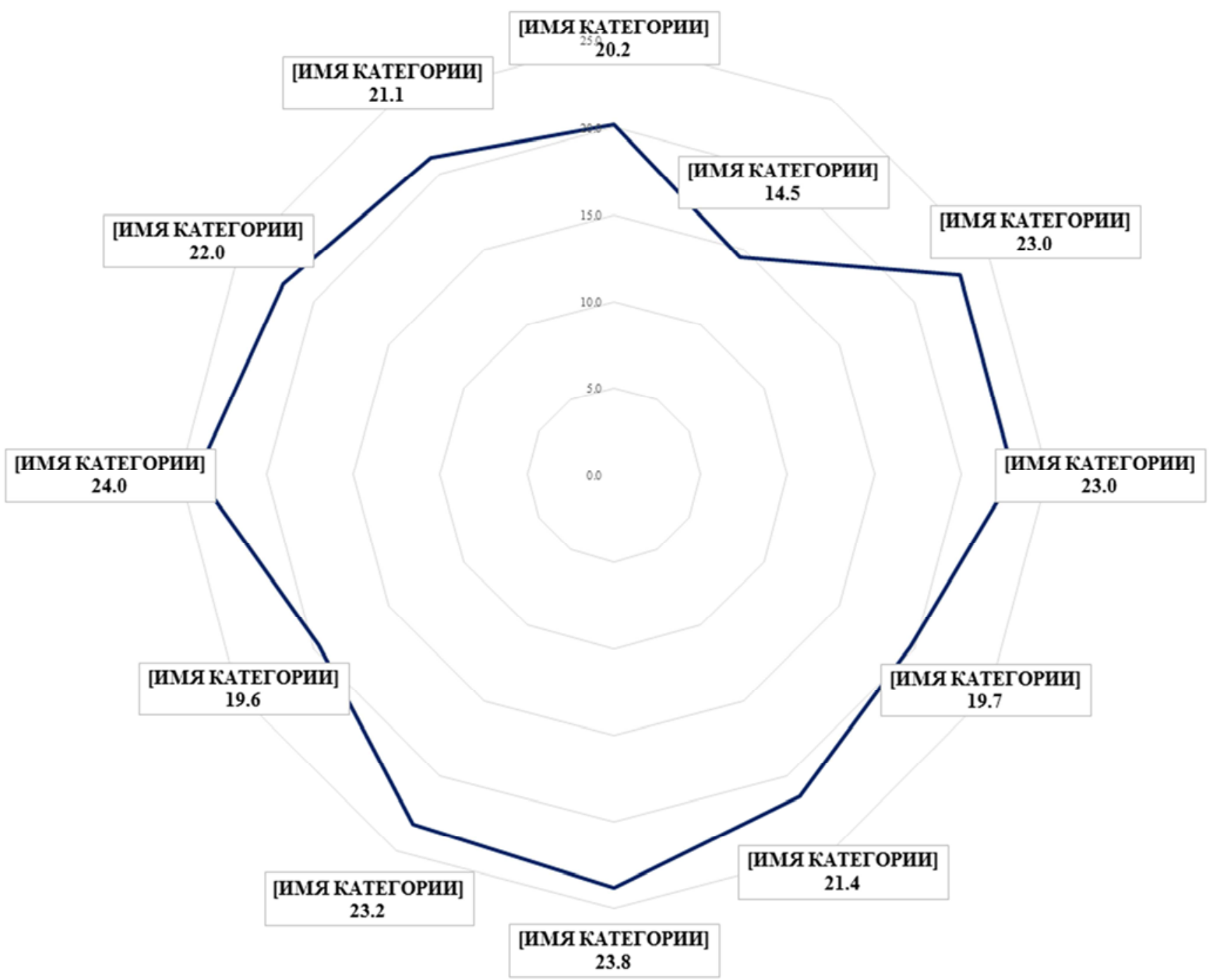

Figure 1. Median 25(OH)D concentration in blood per months.

While comparing vitamin D level in children in various year seasons, we detected the significant difference of summer and winter seasons: $25(\mathrm{OH}) \mathrm{D}$ decrease in winter up to deficiency level $-17.0[11.0 ; 25.0] \mathrm{ng} / \mathrm{ml})$ and increase in 
summer period up to $22.9[18.0 ; 33.0] \mathrm{ng} / \mathrm{ml}(\mathrm{p}=0.001)$. It is evident that despite the significant gain in the higher insolation period, even in summer months, the optimum vitamin D concentration in children residing in Moscow is not achieved.

So the largest decrease up to deficiency level of $25(\mathrm{OH}) \mathrm{D}_{3}$ in blood was observed in winter period with median - $17(11 ; 25)$ $\mathrm{ng} / \mathrm{ml}$, the dominant insufficiency was observed in other months: in spring period - $22.6(14 ; 35) \mathrm{ng} / \mathrm{ml}$, in summer $22.9(18 ; 33) \mathrm{ng} / \mathrm{ml}$, in autumn - $23.0(16 ; 31) \mathrm{ng} / \mathrm{ml}$ (figure 2).

The analysis of the data presented in figure 2 shows that $25(\mathrm{OH}) \mathrm{D}$ median in neither of year seasons achieves the normal level $(30 \mathrm{ng} / \mathrm{ml})$, hereby in winter period, it rather naturally decreases up to minimum values corresponding to vitamin $\mathrm{D}$ deficiency.

The pooled data per months is graphically shown in figure 3 .

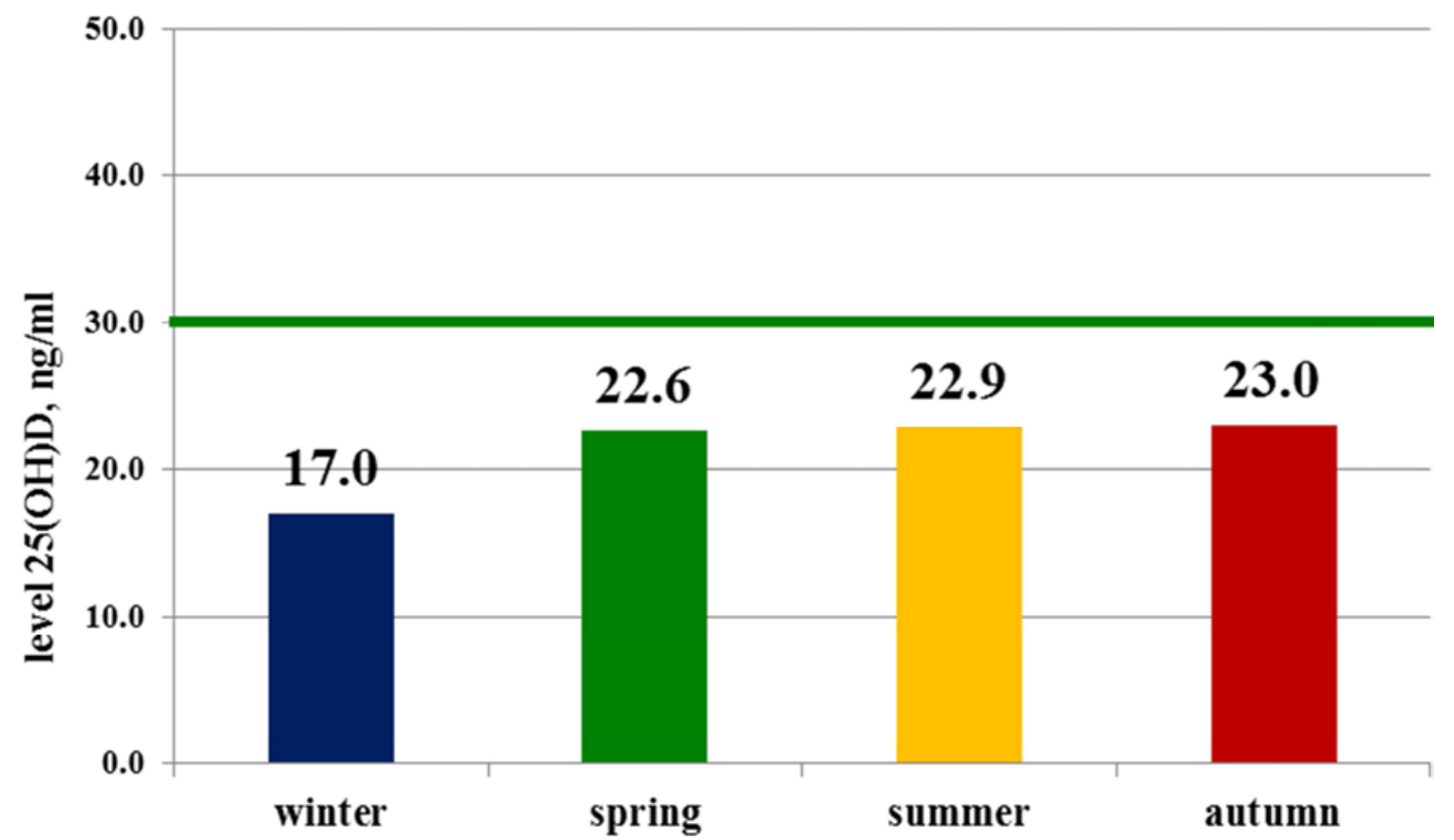

Figure 2. Seasonal variations of 25(OH)D level in children residing in Moscow.

\section{$25(\mathrm{OH}) \mathrm{D} 3 \mathrm{ng} / \mathrm{ml} \quad$ Seasonality of Vitamin D level in children}

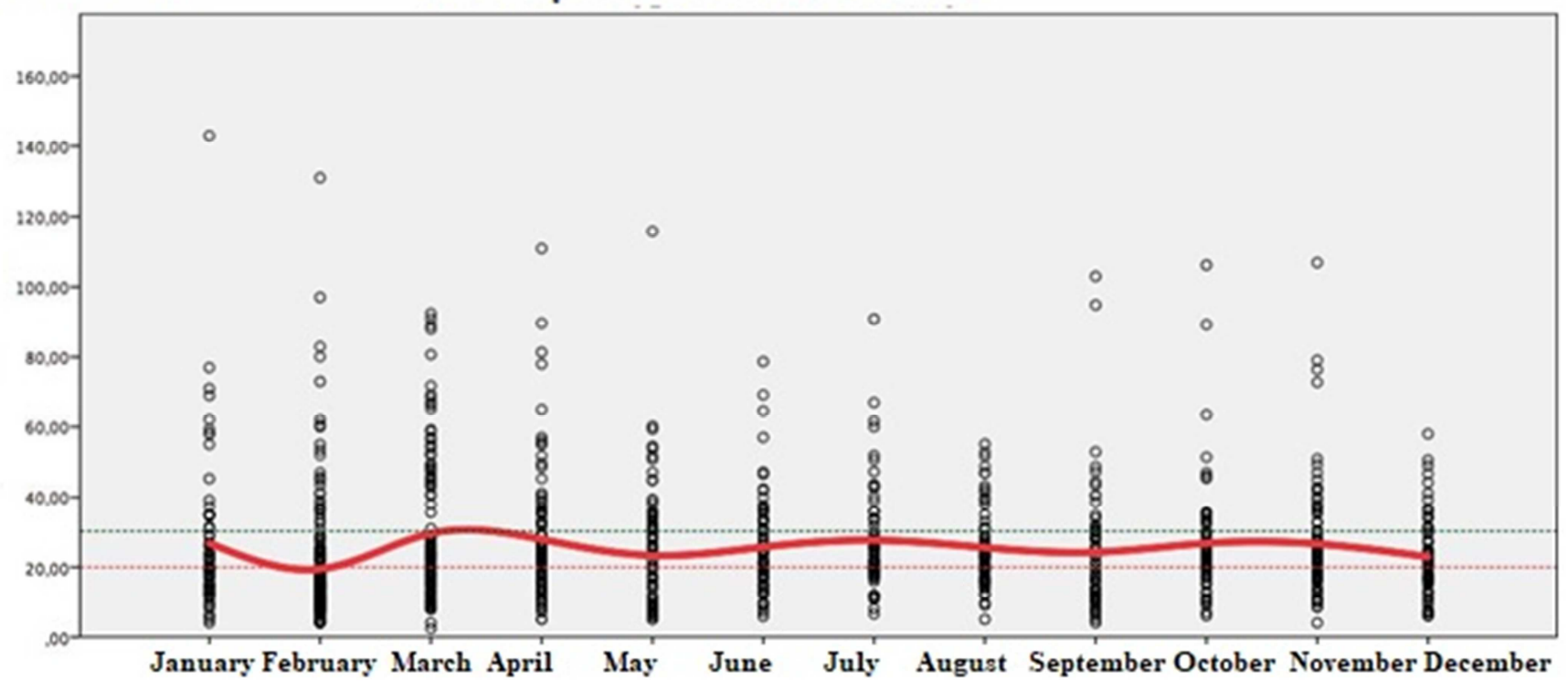

Figure 3. Distribution of $25(\mathrm{OH}) \mathrm{D}$ concentrations per months $(\mathrm{ng} / \mathrm{ml})$ : red line reflects the mean level of vitamin $\mathrm{D}$ in each month; green dashed trends shows the optimum value, and red-deficiency threshold.

Figure 4 presents histogram of calcidiol level distribution in children depending on the age. 


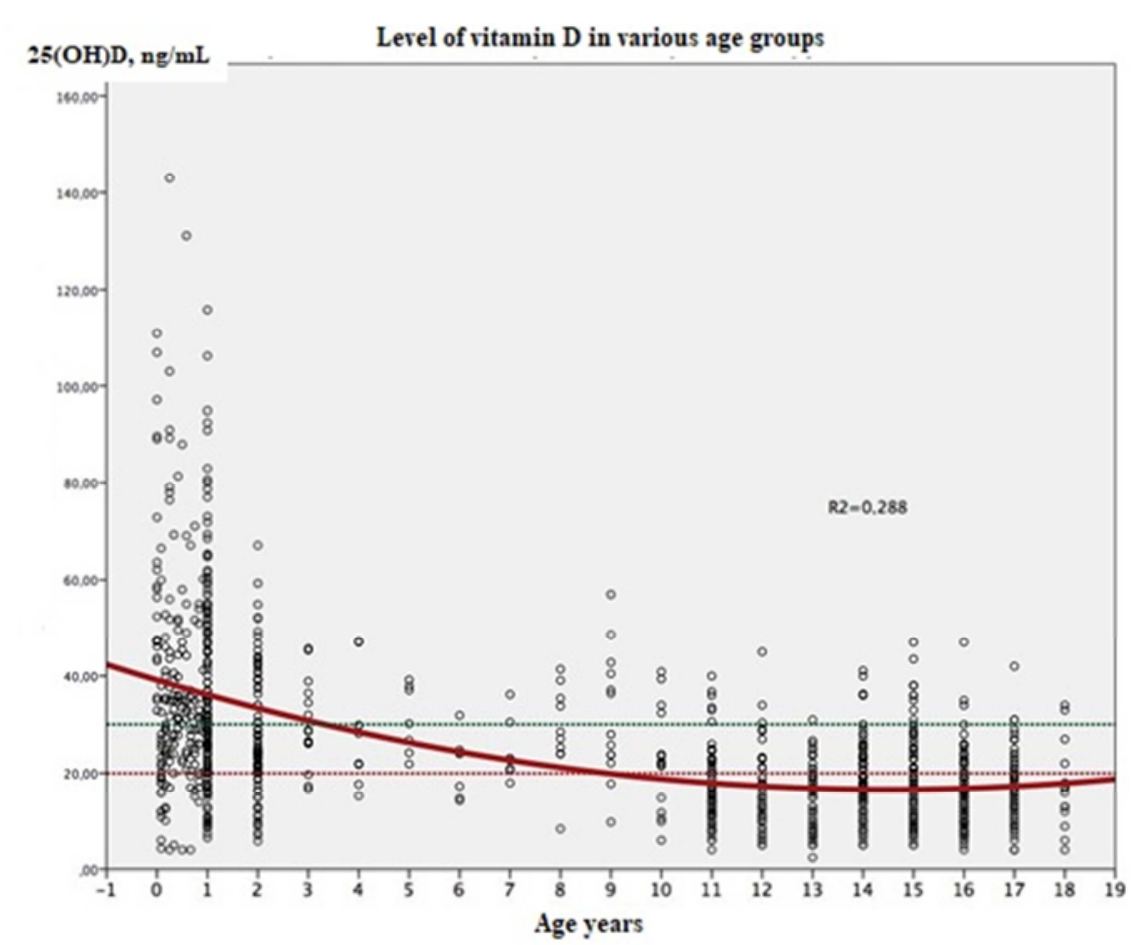

Figure 4. Distribution of 25(OH)D concentrations per age $(\mathrm{ng} / \mathrm{ml})$ : red line reflects the mean level of vitamin D; green dashed trends shows the optimum value, and red-deficiency threshold.

The consistent decrease of calcidiol level with the age is observed on the flow chart, hereby beginning from the age 10 years, 25(OH)D level is decreased to the deficiency zone (below $20 \mathrm{ng} / \mathrm{ml}$ ) in which it stays up to 18 years. It is evident that if enteral products (formula, complementary foods) and vitamin D preparations are present in the first year of children's life, then further exogenous intake of cholecalciferol is decreased, and its endogenous synthesis does not allow to provide the normal vitamin $\mathrm{D}$ levels in the conditions of limited insolation. The decrease of $25(\mathrm{OH}) \mathrm{D}$ level below $20 \mathrm{ng} / \mathrm{ml}$ and maintenance of such a low status throughout the adolescent age inevitably reflects rather negatively on health status of the significant part of the child population.

The high prevalence vitamin D deficiency in all age groups except the group of younger children allows to state inefficacy of available prophylactic actions and unanimously shows the necessity of year-round active D-vitaminization of the diet of children and adolescents.

\section{Discussion and Conclusions}

The presented data demonstrates a rather wide vitamin D deficiency prevalence in all age groups of the child population. This situation described in the Moscow sample of patients confirms the previously published data on the child population of Europe and USA that dictates the necessity of application of new prophylaxis scheme depending on the age $[7,18,19]$.

It is important to understand that child's diet which in the parents' opinion is healthy, covers energy needs and consists of natural products, nevertheless, does not provide a child with sufficient amount of vitamins and micronutrients [20]. The data is especially relevant for vitamin D as its level in the body depends on several conditions and is maintained with the complex regulation system [21,22].

As confirmed in our data on seasonality of vitamin D deficiency in the mid-latitudes as well as in other literature data, in the conditions of city atmosphere pollution, even a child's stay in the sun in summer months does not allow to liquidate vitamin $\mathrm{D}$ deficiency via endogenous synthesis in the skin under effect of UV-rays and achieve its optimum level [14, 23, 24].

Nowadays, the daily vitamin D intake of 400-500 IU/day is recommended for children in Russia during autumn-winter period that according to the large number of clinical studies does not allow to perform effectively mass prophylaxis of hypovitaminosis $\mathrm{D}[7,21,23]$. The needs of a child' body are constantly increasing as he/she grows gradually achieving the needs of an adult that explains the need for the increase of prophylactic cholecalciferol dosages in the older age groups.

According to the European authors, the role of vitamin Doriented nutrition has recently been increasing, hereby diet supplementation promotes maintenance of normal vitamin D levels in children $[18,25]$.

Therefore, the development of vitamin D insufficiency in children and adolescents residing in Moscow may be prevented with the year-round administration of cholecalciferol in the form of food supplements or vitamin products, while vitamin D intake with food and synthesis in the skin is insufficient for maintenance of its adequate level in a child's body. The necessity of development of new clinical recommendations in prophylaxis and treatment of deficient conditions in children is highlighted. 


\section{References}

[1] Gromova O. A., Torshin I. Yu. Vitamin D-change of the paradigm /Edited by E. I. Gusev, I. N. Zakharova-M.:TORUS PRESS, 2015.-464 p.

[2] Hossein-Nezhad A., Spira A., Holick M. F. Influence of vitamin D status and vitamin D3 supplementation on genome wide expression of white blood cells: a randomized doubleblind clinical trial // PloS One.-2013.-Vol 8, № 3.- p. e58725.

[3] Munns C. F., Shaw N., Kiely M., Specker B. L., Thacher T. D., Ozono K., Michigami T., Tiosano D., Mughal M. Z., Mäkitie O., Ramos-Abad L., Ward L., DiMeglio L. A., Atapattu N., Cassinelli H., Braegger C., Pettifor J. M., Seth A., Idris H. W., Bhatia V., Fu J., Goldberg G., Sävendahl L., Khadgawat R., Pludowski P., Maddock J., Hyppönen E., Oduwole A., Frew E., Aguiar M., Tulchinsky T., Butler G., Högler W. Global consensus recommendations on prevention and management of nutritional hypovitaminosis D // Hormone Research in Paediatrics.-2016.-Vol. 85, № 2.-P. 83-106.

[4] Saggese G., Vierucci F., Boot A. M., Czech-Kowalska J., Weber G., Camargo C. A., Mallet E., Fanos M., Shaw N. J., Holick M. F. Vitamin D in childhood and adolescence: an expert position statement // Eur. J. Pediatrics.-2015.-Vol. 174, № 5.-P. 565-576.

[5] Schlögl M., Holick M. F. Vitamin D and neurocognitive function // Clinical Interventions in Aging.-2014.-Vol. 9.-P. 559-568.

[6] Hossein-Nezhad A., Holick M. F. Vitamin D for health: a global perspective // Mayo Clinic Proceedings.-Elsevier, 2013.-Vol. 88, № 7.-P. 720-755.

[7] Gromova O. A., Torshin I. Yu., Zakharova I. N., Spirichev V. B., Limanova O. A., Borovik T. E., Yatsyk G. V. On vitamin D dosing in children and adolescents // Problems of modern pediatrics.-2015.-Volume 14, № 1.-P. 38-47.

[8] Andersen R., Brot C., Jakobsen J., Mejborn H., Mølgaard C., Skovgaard L. T., Trolle E., Tetens I., Ovesen L. Seasonal changes in vitamin D status among Danish adolescent girls and elderly women: the influence of sun exposure and vitamin D intake // Eur. J. Clin. Nutr.-2013.-Vol. 67, № 3.-P. 270 274.

[9] Maxwell J. D. Seasonal variation in vitamin D // Proceedings of the Nutrition Society.-1994.-Vol. 53, № 3.-P. 533-543.

[10] Meier C. Woitge H. W., Witte K., Lemmer B., Seibel M. J. Supplementation with oral vitamin D3 and calcium during winter prevents seasonal bone loss: a randomized controlled open-label prospective trial // Journal of Bone and Mineral Research.-2004.-Vol. 19, № 8.-P. 1221-1230.

[11] Rockell J. E., Green T. J., Skeaff C. M., Whiting S. J., Taylor R. W., Williams S. M., Parnell W. R., Scragg R., Wilson N., Schaaf D., Fitzgerald E. D., Wohlers M. W. Season and ethnicity are determinants of serum 25-hydroxyvitamin D concentrations in New Zealand children aged 5-14 y // The Journal of Nutrition.-2005. - Vol. 135, № 11.-P. 2602-2608.

[12] Davies P. S., Bates C. J., Cole T. J., Prentice A., Clarke P. C. Vitamin D: seasonal and regional differences in preschool children in Great Britain // Eur. J. Clin. Nutr.-1999.--Vol. 53, № 3.-P. 195-198.
[13] Gordon C. M., DePeter K. C., Feldman H. A., Grace E., Emans S. J. Prevalence of vitamin D deficiency among healthy adolescents // Arch. Pediatr. Adolesc. Med.-2004.Vol. 158, № 6.-P. 531-537.

[14] Holick M. F. Evidence-based D-bate on health benefits of vitamin D revisited // Dermato-endocrinology.-2012.-Vol. 4, № 2.-P. 183-190.

[15] Priemel M., von Domarus C., Klatte T. O., Kessler S., Schlie J., Meier S., Proksch N., Pastor F., Netter C., Streichert T., Püschel K., Amling M. Bone mineralization defects and vitamin D deficiency: histomorphometric analysis of iliac crest bone biopsies and circulating 25-hydroxyvitamin D in 675 patients // Journal of Bone and Mineral Research.-2010.Vol. 25, № 2.-P. 305-312.

[16] Zakharova I. N.,Vasilyeva S. V., Dmitrieva Yu. A., Mozzhukhina M. V., Evseeva E. A. Correction of vitamin D insufficiency // Effective pharmacotherapy.-2014.-№. 3.-P. $38-45$.

[17] Wacker M., Holick M. F. Vitamin D-effects on skeletal and extraskeletal health and the need for supplementation // Nutrients.-2013. -Vol. 5, № 1.-P. 111-148.

[18] Holick M. F., Binkley N. C., Bischoff-Ferrari H. A., Gordon C. M., Hanley D. A., Heaney R. P., Murad M. H., Weaver C. M. Evaluation, treatment, and prevention of vitamin D deficiency: an Endocrine Society clinical practice guideline // J. Clin. Endocrinol. Metabolism. -2011.-Vol. 96, № 7.-P. 1911-1930.

[19] Zakharova I. N., Maltsev S. B., Borovik T. E., Yatsyk G. V., Malyavskaya S. I., Vakhlova I. V., Shumatova T. A., Romantsova E. V., Romanyuk F. P., Klimov L. Ya., Pirozhkova N. I., Kolesnikova S. M., Kuryaninova V. A., Vasilyeva S. V., Mozzhukhina M. V., Evseva E. A. The results of multicenter study "Rodnichok" to examine vitamin D insufficiency in younger children in Russia // Pediatrics. G. N. Speransky journal.-2015.-Volume 94, № 1.-P. 62-67.

[20] Kodentsova V. M., Gromova O. A., Makarova S. G. Micronutrients in nutrition of children and use of vitaminmineral complexes // Pediatric pharmacology.-2015.-Volume 12, № 5.-P. 537-542.

[21] Gromova O. A., Torshin I. Yu. Vitamins and minerals between Scylla and Haribda. Edited by E. I. Gusev, V. G. Spirichev. M.: MCNMO, 2013.-693 p.

[22] Thacher T. D., Clarke B. L. Vitamin D insufficiency // Mayo Clin. Proc.-2011.-Vol. 86, № 11.-P. 50-60.

[23] Saygitov R. T. Differentiated ("seasonal") approach in prophylactic of vitamin $\mathrm{D}_{3}$ insufficiency in children // Problems of modern pediatrics.-2009.--Volume 8, № 5.-P.7079.

[24] Pludowski P., Grant W. B., Bhattoa H. P., Bayer M., Povoroznyuk V., Rudenka E., Ramanau H., Varbiro S., Rudenka A., Karczmarewicz E., Lorenc R., Czech-Kowalska J., Konstantynowicz J. Vitamin D status in Central Europe // International Journal of Endocrinology.-2014.-T. 2014.

[25] Kodentsova V. M., Vrzhesinskaya O. A. Fortified food products in nutrition of children: history, problems and prospectives // Problems of pediatric dietology.-2012.Volume 10, № 5.-P. 32-44. 